Грабовенко Наталія Валеріївна кандидат педагогічних наук, доцент, професор кафедри публічного адміністрування, Міжрегіональна Академія управління персоналом, вул. Фрометівська, 2, м. Київ, 03039, тел.: (050) 158-9222, e-mail: natagrabovenko@ukr.net, https://orcid.org/0000-0001-8896-1292.

\title{
МЕХАНІЗМИ ДЕРЖАВНОГО УПРАВЛІННЯ ЯКІСТЮ ЗАГАЛЬНОЇ СЕРЕДНЬОЇ ОСВІТИ
}

Анотація. В статті проаналізовано сутність та механізми державного управління якістю загальної середньої освіти. Систематизовано та узагальнено поняття якості загальної середньої освіти як однієї з центральних категорій науки державного управління; визначено іiі сутність. Розглянуто основні механізми державного управління якістю загальної середньої освіти України як одного 3 пріоритетних напрямів освітньої політики. Визначено, що управління якістю загальної середньої освіти як соціальний процес конструюється діями державних органів залежно від структурних умов та схем самоорганізації. Зазначено, що механізмами державного управління якістю загальної середньої освіти виступає певна структура системи державного управління якістю загальної середньої освіти із певною сукупністю процесів, закономірностей, з яких і складається система управління як соціальне і суспільно-політичне явище.

Запропоновано авторське визначення механізмів державного управління якістю загальної середньої освіти. Це засоби, практичні заходи, які здійснюють органи управління, задля надання якісної освіти учням, щоб результати їх навчання відповідали критеріям вказаним в державних стандартах.

Зазначено, що сучасний стан державного управління системою освіти характеризується процесом децентралізації. Він полягає в тому, що державні органи розробляють стратегічні напрямки розвитку, а регіональні та місцеві органи вирішують конкретні організаційні, фінансові, кадрові, матеріальні проблеми.

Автором наголошено, що механізми державного управління якістю представляють собою сукупність процесів, процедур та технологій взаємодії суб'єктів державного управління й місцевого самоврядування. Розглянуто деякі механізми управління якістю загальної середньої освіти, а саме: ліцензування, моніторинг освіти, атестація та сертифікація педагогічних працівників, підвищення кваліфікації, інституційний аудит, тощо. 
Ключові слова: державне управління, механізми державного управління, загальна середня освіта, державне управління якістю загальної середньої освіти.

Hrabovenko Natalia Valeriivna Candidate of Pedagogic Sciences, docent, Professor of the Department of Public Administration, Interregional Academy of Personnel Management (IAPM), Frometivska St., 2, Kyiv, 03039, tel.: (050) 158-92-22, e-mail: natagrabovenko@ukr.net; https://orcid.org/0000-0001-8896-1292.

\section{MECHANISMS OF PUBLIC QUALITY MANAGEMENT OF GENERAL SECONDARY EDUCATION}

Abstract. The article analyzes the essence and mechanisms of state quality management of general secondary education. The notion of quality of general secondary education as one of the central categories of public administration science is systematized and generalized; its essence is defined. The main mechanisms of state management of the quality of general secondary education in Ukraine as one of the priority areas of educational policy are considered. It is determined that the quality management of general secondary education as a social process is constructed by the actions of state bodies depending on the structural conditions and schemes of selforganization. It is noted that the mechanisms of public quality management of general secondary education is a certain structure of the public quality management system of general secondary education with a certain set of processes, patterns, which make up the management system as a social and socio-political phenomenon. The author's definition of mechanisms of state management of quality of general secondary education is offered.

These are tools, practical measures taken by government agencies to provide quality education to students so that their learning outcomes meet the criteria specified in state standards. It is noted that the current state of public administration of the education system is characterized by the process of decentralization.

It consists in the fact that state bodies develop strategic directions of development, and regional and local bodies solve concrete organizational, financial, personnel, material problems. The author emphasizes that the mechanisms of public quality management are a set of processes, procedures and technologies of interaction between public administration and local government.

Some mechanisms of quality management of general secondary education are considered, namely: licensing, monitoring of education, attestation and certification of pedagogical workers, advanced training, institutional audit, etc.

Keywords: public administration, mechanisms of public administration, general secondary education, public quality management of general secondary education.

Постановка проблеми. Питання розвитку загальної середньої освіти $€$ 
досить актуальною проблемою сьогодення. Пріоритетним завданням державної політики в галузі освіти є забезпечення високої якості освіти, заснованої на фундаментальності знань та розвитку творчих компетентностей учнів відповідно потребам особистості, суспільства й держави, безпеки освітнього процесу та забезпечення здоров'я дітей за умови постійного розвитку професійного потенціалу працівників освіти. При цьому все більш очевидними і актуальними стають механізми, що забезпечують реалізацію нових вимог до якості загальної освіти в Україні.

Аналіз останніх досліджень та публікацій. Дослідженням механізмів державного управління займались такі вчені, як В. Авер'янов, Г. Атаманчук, В. Бакуменко, Ю.Древаля, В. Князев, В.Кравченко, Н. Нижник, В. Рижих, I. Розпутенко, В. Шамрай, О. Шапоренко та ін.

Наукові праці у сфері державного управління освітою мають Л. Гаєвська, Д. Дзвінчук, В. Луговий, Т. Лукіна, О. Матвієнко, Л. Паращенко, В. Огаренко, I. Семенець-Орлова, В. Шилова та ін..

Мета статті $\epsilon$ визначення комплексу механізмів державного управління якістю загальної середньої освіти.

Виклад основного матеріалу. Сучасний зміст вимог до якості загальної освіти визначається, в першу чергу, споживачами і зацікавленими сторонами освітніх послуг. Споживачами освітніх послуг є учні та їх батьки, а також держава, установи професійної освіти, ринок праці і, при певних умов, бізнестовариство.

Ключові напрями й принципи розвитку освіти відображені в нормативноправових документах державної освітньої політики. На думку Д. Дзвінчука, серед них виділяють наступні: рівний доступ до якісної освіти; особлива увага до навчальних результатів; розширення засобів і форм освіти; інформатизація навчання, зміцнення партнерських відносин навчального закладу i педагогів 3 громадою і соціумом в цілому [1].

Законодавство України про загальну середню освіту складається 3 Конституції України [2], Закону України “Про освіту”[3], “Про повну загальну середню освіту" [4], інших актів законодавства у сфері освіти і науки та міжнародних договорів України, укладених в установленому законом порядку [5]. Управління якістю загальної середньої освіти як соціальний процес конструюється діями державних органів залежно від структурних умов та схем самоорганізації. Варто наголосити, що у 2020 році було прийнято Закон України “Про повну загальну середню освіту" що дало змогу системі управління якістю загальної середньої освіти відтворювати існуючу структуру і змінюватися під впливом зовнішніх і внутрішніх впливів. Необхідно зазначити, що якість освіти прямо залежить від функціонування державних механізмів. 
Розглянемо поняття “механізми державного управління”. На думку В. Кравченка це “способи розв’язання суперечностей явища чи процесу в державному управлінні, послідовна реалізація дій, які базуються на основоположних принципах, цільовій орієнтації, функціональній діяльності 3 використанням відповідних їй форм і методів управління” [6, с. 421].

Варто наголосити, що якщо йде мова про загальну середню освіту, то під цим терміном ми розуміємо систематизовану та передбачену відповідними державними стандартами сукупність результатів навчання і компетентностей, здобутих особою на рівнях початкової, базової середньої та профільної середньої освіти. Отже, якість загальної середньої освіти - це відповідність результатів навчання, тобто знання, отримані учнем на відповідних рівнях загальної середньої освіти відповідно до критеріїв державних стандартів.

Детально зупинимось на понятті "механізми державного управління в загальній середній освіті". Воно зафіксовано в “Енциклопедичному словнику 3 державного управління" та визначається як “практичні заходи, засоби за допомогою яких реалізуються державноуправлінський вплив на галузь шкільної освіти. Також виділено такі основні групи цих механізмів, а саме: правові; організаційні, фінансово-економічні; кадрові; соціальні; мотиваційні; матеріально-технічні, інформаційні; управління інноваційним розвитком, управління якістю [6, с. 421].

Механізмами державного управління якістю загальної середньої освіти, також, слід зазначити, виступає певна структура системи державного управління якістю загальної середньої освіти із зазначеною сукупністю процесів, закономірностей, 3 яких i складається система управління як соціальне $\mathrm{i}$ суспільно-політичне явище.

До державних органів із забезпечення якості освіти входять органи виконавчої влади та його територіальні органи, спеціально уповноважені державою органи, які здійснюють зовнішнє оцінювання якості освіти у галузі загальної середньої освіти належить органам управління та установам, установи що здійснюють зовнішнє незалежне оцінювання, місцеві державні адміністрації та органи місцевого самоврядування, акредитовані професійні асоціації, інші акредитовані юридичні особи, які самостійно оцінюють якість освіти та освітню діяльність навчальних закладів [4].

Необхідно звернути увагу, що система забезпечення якості у сфері загальної середньої освіти формується відповідно до Закону України "Про освіту" , та містить такі складові:

- внутрішня система забезпечення якості освіти в закладах освіти;

- система зовнішнього забезпечення якості освіти;

- система забезпечення якості в діяльності органів управління та установ, що 
- здійснюють зовнішнє забезпечення якості освіти [3].

Отже, механізми державного управління якістю загальної середньої освіти представляють комплекс процесів, процедур та технологій взаємодії суб'єктів державного управління й місцевого самоврядування. Механізми можемо розділити на два види: зовнішні - що задають порядок діяльності будь-якому об'єкту, та внутрішні.

Зовнішні механізми виконують сполучну функцію між діяльністю державних та громадсько-управлінських структур.

Розглянемо внутрішні механізми якості освіти, вони формуються навчальним закладом і включають механізми забезпечення академічної чесності, порядок виявлення та встановлення фактів іiї порушення, види відповідальності педагогів і учнів за конкретні порушення академічної чесності. Керівник та інші педагогічні працівники закладу освіти забезпечують дотримання принципів академічної доброчесності згідно своєї компетентності.

Іншим механізмом державного управління якістю загальної середньої освіти є державні стандарти. Вони розроблені та затверджені для відповідних рівнів освіти: для початкової, базової середньої та спеціалізованої середньої освіти, а також містять вимоги до результатів навчання учнів в освітніх секторах. Вони описують загальне навантаження учнів на відповідному рівні повної загальної середньої освіти.

Слід зазначити, що рішення задач ліцензування та акредитації освітніх установ, вдосконалення педагогічного корпусу, організації системи дистанційної освіти є забезпеченням сучасної організації та якістю у сфері загальної середньої освіти.

Варто наголосити освітні установи можуть проводити освітню діяльність на певному рівні загальної середньої освіти на підставі ліцензії. Ліцензія видається спеціальним органом, що ліцензує відповідно до вимог Закону України "Про ліцензування видів господарської діяльності" [7].

Інституційний аудит як механізм державного управління якістю середньої освіти є комплексною зовнішньою перевіркою і оцінку освітніх та управлінських процесів закладу загальної середньої освіти, які повинні забезпечувати його ефективну роботу і забезпечити сталий розвиток. Проводиться аудит не тільки 3 метою оцінки , а й з визначення рекомендацій задля якості освітньої діяльності навчального закладу. Ці рекомендації пропонуються засновнику установи загальної середньої освіти задля:

- підвищення якості освітньої діяльності та вдосконалення внутрішньої системи забезпечення якості освіти;

- приведення освітніх і управлінських процесів відповідно умовам ліцензування. Це грунтується на процедурі проведення інституційного аудиту, яка 
затверджується центральним органом виконавчої влади в галузі освіти і науки та подається центральним органом виконавчої влади $[4,8]$.

Зовнішнє незалежне оцінювання є однією 3 форм оцінювання результатів навчання, здобутих учнями на рівнях базової чи профільної середньої освіти. Результати зовнішнього незалежного оцінювання, можуть використовуватися для зарахування до ліцеїв та інших закладів освіти, що забезпечують здобуття профільної середньої освіти.

Істотний вплив на якість освіти надають педагогічні кадри. Це вплив визначається цілою низкою чинників: рівнем освіти, завантаженістю вчителя, стажем педагогічної діяльності, ступенем мотивації. Завантаженість впливає на якість професійної діяльності, можливість забезпечення індивідуального підходу до учнів, самостійного підвищення кваліфікації.

Задля забезпечення здобуття фахових компетентностей спеціалізованої освіти педагогами, проводиться атестація педагогічних працівників. За їі результатами визначається відповідність педагогічного працівника займаній посаді, присвоюється або підтверджується кваліфікаційна категорія та може бути присвоєне педагогічне звання [9].

Якщо мова йде про сертифікацію педагогічних працівників, то вона проводиться 3 метою виявлення та заохочення педагогічних працівників 3 високим рівнем педагогічної майстерності, які володіють методиками навчання $\mathrm{i}$ новими освітніми технологіями та сприяють їх поширенню.

Слід відмітити, що ресурсне (інформаційне, науково-методичне, матеріальнотехнічне) забезпечення якісної освіти є провідним інструментом забезпечення якісної освіти сьогодення.

Матеріально-технічне забезпечення пов'язано 3 наявністю обладнаних кабінетів: фізики, хімії, біології, спортивних і актових залів, оснащенням освітнього процесу лабораторним обладнанням, робототехнікою, засобами інформатизації, забезпеченням доступу до мережі Інтернет, надання доступу до публічних освітніх, наукових та інформаційних ресурсів, надання електронних підручників та інших мультимедійних навчальних.

Важливо зазначити, що сучасний стан державного управління системою освіти характеризується процесом децентралізації. Він полягає в тому, що державні органи розробляють стратегічні напрямки розвитку, а регіональні та місцеві органи вирішують конкретні організаційні, фінансові, кадрові, матеріальні проблеми. Втім зазначений поділ відповідальності характерний для державних структур управління. 3 метою демократизації цього процесу поряд 3 державними створюються громадські органи управління системою освіти. Вони складаються 3 представників педагогічного, учнівського колективів, батьків та громадськості. Найважливішою ознакою громадського характеру управління системою освіти, 
крім створення колегіального органу управління, $є$ роздержавлення (створення недержавних навчальних закладів) і диверсифікованість освітніх установ [10].

Також, в якості внутрішнього механізму в державному управлінні діє соціальна інформатизація, що виражається громадською думкою, i активною соціальною позицією громадян. Розглянемо внутрішній механізм, що стосується збору інформації та розвитку ініціативи і соціальної свідомості населення: моніторинг, проведення зборів громадськості, опитування, волонтерські акції, розвиток партнерських відносин і т.д.

Моніторинг як систематичне відстеження процесів або тенденцій 3 метою своєчасної оцінки ситуації для коригування дій в процесі досягнення мети. Сутність концепції моніторингу полягає в синхронності процесів спостереження, вимірювання, вироблення на цій основі нових знань про стан об'єкта та подальші моделювання, прогнозування та прийняття відповідних управлінських рішення. Освітній моніторинг функціонально пов'язаний 3 усіма етапами управління, утворюючи з ними замкнутий цикл регулювання [9].

Висновок. Таким чином, розглянувши механізми, виділимо, що вони полегшують процедуру оцінки якості загальної середньої освіти. Така оцінка забезпечує зворотній зв'язок, необхідний для прийняття управлінських рішень в цілях сталого функціонування та розвитку системи освіти. Механізми державного управління якістю представляють собою сукупність процесів, процедур та технологій взаємодії суб'єктів державного управління й місцевого самоврядування. Отже, механізми державного управління якістю загальної середньої освіти - це засоби, практичні заходи, які здійснюють органи управління в галузі загальної середньої освіти, задля надання якісної освіти учням, щоб результати їх навчання на відповідних рівнях відповідали критеріям державним стандартів.

\section{Лimepamypa:}

1. Дзвінчук Д. Освіта в історико-філософському вимірі: тенденції розвитку та управління : монографія Київ. 2006. 378 с.

2. Конституція України URL: https://zakon.rada.gov.ua/laws/show/254\%D0\%BA/96$\% \mathrm{D} 0 \% \mathrm{~B} 2 \% \mathrm{D} 1 \% 80 \#$ Text

3. Закон України “Про освіту”. URL: https://zakon.rada.gov.ua/laws/show/2145-19\#Text

4. Закон України “Про повну загальну середню освіту”. URL: https://zakon.rada.gov.ua/laws/show/848-19\#Text

5. Національна доктрина розвитку освіти України. 2004. Ч.1. С. 5-24.

6. Енциклопедичний словник з державного управління. Київ. 2010. 820 с.

7. Закон України "Про ліцензування видів господарської діяльності" URL: https://zakon.rada.gov.ua/laws/show/222-19\#Text.

8. Семенець-Орлова I. Ціннісні засади державної політики щодо розвитку освіти в Україні. Проблеми управління соціальним і гуманітарним розвитком: XIII наук.-практ. конф. за 
міжнар. уч., 29 листопада 2019 р. Дніпро, 2019. С. 530-533.

9. Лукіна Т. Державне управління якістю загальної середньої освіти в Україні. Київ. 2005.

10. Паращенко Л. Державне управління розвитком загальної середньої освіти в Україні: методології, стратегії, механізми: [монографія]. Київ, 2011. 536 с.

11. Матвієнко О. Стратегії розвитку середньої освіти в країнах Європейського Союзу : монографія Київ. 2005. 381 с.

\section{Reference:}

1. Dzvinchuk D. (2006). Osvita v istoryko-filosofskomu vymiri: tendentsii rozvytku ta upravlinnia : monohrafiia Kyiv. [in Ukrainian].

2. Konstytutsiia Ukrainy. Retrieved from: https://zakon.rada.gov.ua/laws/show/254\%D0\%BA/ 96-\%D0\%B2\%D1\%80\#Text. [in Ukrainian].

3. Zakon Ukrainy Pro osvitu. Retrieved from: https://zakon.rada.gov.ua/laws/show/214519\#Text. [in Ukrainian].

4. Zakon Ukrainy Pro povnu zahalnu seredniu osvitu. Retrieved from: https://zakon.rada.gov.ua/laws/show/848-19\#Text. [in Ukrainian].

5. Natsionalna doktryna rozvytku osvity Ukrainy (2004). Ch.1. [in Ukrainian].

6. Entsyklopedychnyi slovnyk z derzhavnoho upravlinnia. Kyiv. 2010. 820 s. [in Ukrainian].

7. Zakon Ukrainy Pro litsenzuvannia vydiv hospodarskoi diialnosti. Retrieved from: https://zakon.rada.gov.ua/laws/show/222-19\#Text. [in Ukrainian].

8. Semenets'-Orlova I. (2019). Tsinnisni zasady derzhavnoi polityky schodo rozvytku osvity v Ukraini. Problemy upravlinnia sotsial'nym i humanitarnym rozvytkom: '19 KhIII nauk.-prakt. konf. za mizhnar. uch. (pp. 530-533). Dnipro. [in Ukrainian].

9. Lukina T. (2005). Derzhavne upravlinnia yakistiu zahalnoi serednoi osvity v Ukraini. Kyiv. [in Ukrainian].

10. Parashchenko L. (2011). Derzhavne upravlinnia rozvytkom zahalnoi serednoi osvity v Ukraini: metodolohii, stratehii, mekhanizmy: [monohrafiia]. Kyiv. [in Ukrainian].

11. Matviienko O. (2005). Stratehii rozvytku serednoi osvity v krainakh Yevropeiskoho Soiuzu : monohrafiia Kyiv. [in Ukrainian]. 